\title{
To Evaluate the effect of OM Mantra Chanting along with Anulom Vilom Pranayama on Medical and Paramedical Students
}

\author{
Bittoo Kumar Surlya ${ }^{1}$, Dr. Manila Jain ${ }^{2 *}$
}

${ }^{1}$ Assistant Professor, Physiology, Chirayu Medical College and Hospital, Bhopal, India

${ }^{2}$ Professor and Head, Department of Physiology, Malwanchal University Index Medical College, Hospital \& Research Centre, Nemawar Rd, post Bavlia near Khudel, village, Indore, Madhya Pradesh 452016, India

DOI: 1 10.36348/sijap.2021.v04i03.005 | Received: 27.02.2021 | Accepted: 17.03.2021 | Published: 30.03 .2021

*Corresponding author: Dr. Manila Jain

\section{Abstract}

Introduction: Mantra: In its most rudimentary form, a mantra is made of syllables which exert their influence by means of sound (vibrations). As one would have personally experienced, different syllables have different vibration patterns which affect different parts of the body. Material and Methods: This is prospective and observational study. Inclusion Criteria: Males and females with Age group 20-30 years old. Exclusion Criteria: Significant cardiovascular and respiratory systems complications, Thyroid disorders, Uncontrolled diabetes mellitus, Addiction to alcohol and Smoker. Results: In the pre-intervention, study group had a mean HR value of $73.46 \pm 2.78$, which has been decreased to $67.36 \pm 2.66$ in the post intervention, which was found to be highly significant $(\mathrm{P}=<0.003)$. Similarly, the control group had a mean HR value of $74.12 \pm 2.35$ which has been decreased to $73.24 \pm 3.21$, the decrease was not statistically significant $(\mathrm{P}=0.064)$. In the post intervention, study group had a mean heart rate $(67.36 \pm 2.66)$ and control group had a mean heart rate $(73.24 \pm 3.21)$ the change in the HR in the two groups differed. Whereas study group had greater decrease in HR compared to control group. Which was found to be highly significant $(\mathrm{P}=0.002)$. Conclusion: To summarize, our study demonstrates that pranayama practice is effective in reducing perceived stress but significant benefit on physiological parameters is seen in only study subjects practicing pranayama.

Keywords: OM Mantra Chanting, Anulom Vilom Pranayama, Medical students.

Copyright (C) 2021 The Author(s): This is an open-access article distributed under the terms of the Creative Commons Attribution 4.0 International License (CC BY-NC 4.0) which permits unrestricted use, distribution, and reproduction in any medium for non-commercial use provided the original author and source are credited.

\section{INTRODUCTION}

Mantra: In its most rudimentary form, a mantra is made of syllables which exert their influence by means of sound (vibrations). As one would have personally experienced, different syllables have different vibration patterns which affect different parts of the body [1]. Each syllable resonates with certain organ or part of the body. For example, by chanting "'aaaaaaa", one can feel the sensation and hence resonance of nervous system in the stomach and chest region. Chanting "'uuuu" creates sensations in the throat and chest region and resonates with them. Similarly, chanting/humming "mmtnm" resonates with the nasal cavity as well as the skull/brain region [2].

When we concatenate (join together) the above syllables into one mantra. We get the Om mantra which when chanted, sequentially activates the stomach, spinal cord, throat, nasal and brain regions. The energy moves from the abdomen all the way up to the brain, thereby channelizing energy and activating the spinal cord and brain [3]. One of the most popular claims made by Yogis is that chanting Om mantra improves our concentration, gives peace and steadiness to our mind, reduces mental stress and clears all worldly thoughts. Although those who practise it regularly would have experienced it first hand and affirm the same, scientists were curious to find out more about it and verify such claims with the help of science and technology [4].

Om meditation is said to cure many illnesses. The vibrations that it creates give a sense of positivity to our life. It is believed that Om meditation takes you closer to God. Om meditation brings in self-realization and a feeling of oneness with the Lord. Om meditation is believed to be a stress buster [5]. It helps in calming the brain. Studies show that meditation also helps in relieving the symptoms of posttraumatic stress disorder. Om meditation works wonders for those with low selfesteem if they practise meditation regularly. The word 'Om' contains a cosmic positive energy which helps in 
creating positive vibrations and gives a divine feeling. Among all benefits that 30 meditation offers, the most important of all is that it helps you relieve yourself from thoughts that obstruct your thinking process. Also, one can practise Sakshi Bhavana while meditating. Sakshi Bhavana is a process in yoga where you witness thoughts coming in and going out of your mind [6].

Material and Methods: This is prospective and observational study.

Inclusion Criteria: Males and females with Age group 20-30 years old

\section{Exclusion Criteria:}

- Significant cardiovascular and respiratory systems complications

- Thyroid disorders

- Uncontrolled diabetes mellitus

- Addiction to alcohol

- Smoker

\section{METHOD}

Total 80 students of Medical and paramedical students were participated for this study. They were divided into study group (40) and control group (40).

The study group were practice Om Mantra chanting along with Anulom Vilom Pranayama daily for 40 minutes. Anulom Vilom Pranayama for 10 minutes.

OM Mantra chanting meditation for 20 minutes and 10 minutes for relaxation (5 minutes preceding the OM Mantra Chanting and 5 minutes post meditation)

The control group were not practice Om Mantra chanting along with Anulom Vilom Pranayama) during study. Study group were not performed any physical exercises or any type of yogic exercises during the study.

\section{RESULTS}

Table-1: Age distribution of patients studied

\begin{tabular}{|l|l|l|l|l|}
\hline \multirow{2}{*}{ Age in groups (Years) } & \multicolumn{2}{|l|}{ Study Group } & \multicolumn{2}{l|}{ Control Group } \\
\cline { 2 - 5 } & No & Percentage & No & Percentage \\
\hline $20-22$ & 19 & 47.5 & 21 & 52.5 \\
\hline $23-25$ & 13 & 32.5 & 11 & 27.5 \\
\hline $26-28$ & 7 & 17.5 & 6 & 15 \\
\hline $29-30$ & 1 & 2.5 & 2 & 5 \\
\hline Total & 40 & 100 & 40 & 100 \\
\hline Mean \pm SD & $21.43 \pm 1.21$ & $22.02 \pm 1.43$ \\
\hline
\end{tabular}

In Table-1, the mean age of the subjects was $21.43 \pm 1.21$ for study group, $22.02 \pm 1.43$ for control group. These differences were not statistically significant $(\mathrm{p}=2.32)$

Table-2: Comparison of before and after 3 months HR between study and control group

\begin{tabular}{|l|l|l|l|}
\hline HR (Beats/min) & Study Group & Control Group & p value \\
\hline Before $(\mathrm{n}=40)$ Mean \pm SD & $73.46 \pm 2.78$ & $74.12 \pm 2.35$ & 0.401 \\
\hline After 3 months $(\mathrm{n}=40)$ Mean \pm SD & $67.36 \pm 2.66$ & $73.24 \pm 3.21$ & 0.002 \\
\hline p value & 0.003 & 0.709 & \\
\hline
\end{tabular}

Heart rate (HR), Values are expressed as mean \pm SD.

In the pre-intervention, study group had a mean HR value of $73.46 \pm 2.78$, which has been decreased to $67.36 \pm 2.66$ in the post intervention, which was found to be highly significant $(\mathrm{P}=<0.003)$. Similarly, the control group had a mean HR value of $74.12 \pm 2.35$ which has been decreased to $73.24 \pm 3.21$, the decrease was not statistically significant $(\mathrm{P}=0.064)$.
In the post intervention, study group had a mean heart rate $(67.36 \pm 2.66)$ and control group had a mean heart rate $(73.24 \pm 3.21)$ the change in the HR in the two groups differed. Whereas study group had greater decrease in HR compared to control group. Which was found to be highly significant $(\mathrm{P}=0.002)$. 
Bittoo Kumar Surlya \& Manila Jain; Sch Int J Anat Physiol, Mar., 2021; 4(3): 38-43

Table-3: Comparison of before and after 3 months PP between study and control group

\begin{tabular}{|l|l|l|l|}
\hline PP $(\mathbf{m m}$ Hg) & Study Group & Control Group & p value \\
\hline Before $(\mathrm{n}=40)$ Mean \pm SD & $56.24 \pm 2.12$ & $53.43 \pm 1.32$ & 0.711 \\
\hline After 3 months $(\mathrm{n}=40)$ Mean \pm SD & $53.29 \pm 14.54$ & $54.44 \pm 1.43$ & 0.002 \\
\hline p value & 0.003 & 0.624 & \\
\hline
\end{tabular}

Pulse Pressure (PP), Values are expressed as mean \pm SD.

In the pre-intervention, study group had a mean PP value of $56.24 \pm 2.12$, which has been decreased to $53.29 \pm 14.54$ in the post intervention, which was found to be highly significant $(\mathrm{P}=0.003)$. Similarly, the control group had a mean PP value of $53.43 \pm 1.32$ which has been decreased to $54.44 \pm 1.43$, the decrease was not statistically significant $(\mathrm{P}=0.624)$.
In the post intervention, study group had a mean Pulse Pressure (53.29 \pm 14.54$)$ and control group had a mean heart rate $(54.44 \pm 1.43)$ the change in the PP in the two groups differed. Whereas study group had greater decrease in PP compared to control group. Which was found to be highly significant $(\mathrm{P}=0.002)$.

Table-4: Comparison of before and after 3 months SP between study and control group

\begin{tabular}{|l|l|l|l|}
\hline SP $(\mathbf{m m H g})$ & Study Group & Control Group & p value \\
\hline Before $(\mathrm{n}=40)$ Mean \pm SD & $120.45 \pm 2.48$ & $120.32 \pm 1.44$ & 0.824 \\
\hline After 3 months $(\mathrm{n}=40)$ Mean \pm SD & $116.38 \pm 2.65$ & $119.43 \pm 2.12$ & 0.005 \\
\hline p value & 0.002 & 0.531 & \\
\hline
\end{tabular}

Systolic blood pressure (SBP), Values are expressed as mean \pm SD.

In the pre-intervention, study group had a mean Systolic blood pressure value of $120.45 \pm 2.48$, which has been decreased to $116.38 \pm 2.65$ in the post intervention, which was found to be highly significant $(\mathrm{P}=0.002)$. Similarly, the control group had a mean SP value of $120.32 \pm 1.44$ which has been decreased to $119.43 \pm 2.12$, the decrease was not statistically significant $(\mathrm{P}=0.531)$.
In the post intervention, study group had a mean SP (116.38 \pm 2.65$)$ and control group had a mean heart rate $(119.43 \pm 2.12)$ the change in the SP in the two groups differed. Whereas study group had greater decrease in SP compared to control group. Which was found to be highly significant $(\mathrm{P}=0.005)$.

Table-5: Comparison of before and after 3 months DP between study and control group

\begin{tabular}{|l|l|l|l|}
\hline DP $(\mathbf{m m H g})$ & Study Group & Control Group & p value \\
\hline Before $(\mathrm{n}=40)$ Mean \pm SD & $83.89 \pm 2.32$ & $82.46 \pm 1.26$ & 0.535 \\
\hline After 3 months $(\mathrm{n}=40)$ Mean \pm SD & $76.48 \pm 2.84$ & $80.84 \pm 1.48$ & 0.004 \\
\hline p value & 0.001 & 0.424 & \\
\hline
\end{tabular}

Diastolic blood pressure (DBP), Values are expressed as mean \pm SD.

In the pre-intervention, study group had a mean Diastolic blood pressure value of $83.89 \pm 2.32$, which has been decreased to $76.48 \pm 2.84$ in the post intervention, which was found to be highly significant $(\mathrm{P}=0.001)$. Similarly, the control group had a mean DP value of $82.46 \pm 1.26$ which has been decreased to $80.84 \pm 1.48$, the decrease was not statistically significant $(\mathrm{P}=0.424)$.
In the post intervention, study group had a mean DP (76.48 \pm 2.84$)$ and control group had a mean heart rate $(80.84 \pm 1.48)$ the change in the DP in the two groups differed. Whereas study group had greater decrease in SP compared to control group. which was found to be highly significant $(\mathrm{P}=0.004)$.

Table-6: Comparison of Before and After 3 months MAP between study and control group

\begin{tabular}{|l|l|l|l|}
\hline MAP $(\mathbf{m m}$ Hg) & Study Group & Control Group & p value \\
\hline Before $(\mathrm{n}=40)$ Mean \pm SD & $88.94 \pm 7.96$ & $87.24 \pm 4.52$ & 0.424 \\
\hline After 3 months $(\mathrm{n}=40)$ Mean \pm SD & $86.87 \pm 5.76$ & $87.23 \pm 4.10$ & 0.041 \\
\hline p value & 0.001 & 0.315 & \\
\hline
\end{tabular}

Mean Arterial Pressure (MAP), Values are expressed as mean \pm SD.

In the pre-intervention, study group had a Mean Arterial Pressure value of $88.94 \pm 7.96$, which has been decreased to $86.87 \pm 5.76$ in the post intervention, which was found to be highly significant $(\mathrm{P}=0.001)$. Similarly, the control group had a mean MAP value of 
Bittoo Kumar Surlya \& Manila Jain; Sch Int J Anat Physiol, Mar., 2021; 4(3): 38-43

$87.24 \pm 4.52$ which has been decreased to $87.233 \pm 4.10$, the decrease was not statistically significant $(\mathrm{P}=0.424)$.

In the post intervention, study group had a mean MAP (86.87 \pm 5.76$)$ and control group had a mean heart rate $(87.233 \pm 4.10)$ the change in the MAP in the two groups differed. Whereas study group had greater decrease in SP compared to control group. Which was found to be highly significant $(\mathrm{P}=0.041)$.

Table-7: Comparison of before and after 3 months RR between study and control group

\begin{tabular}{|l|l|l|l|}
\hline RR (breaths/min) & Study Group & Control Group & p value \\
\hline Before $(\mathrm{n}=40)$ Mean \pm SD & $17.40 \pm 2.13$ & $17.39 \pm 2.03$ & 0.562 \\
\hline After 3 months $(\mathrm{n}=40)$ Mean \pm SD & $14.73 \pm 1.04$ & $17.01 \pm 1.13$ & 0.001 \\
\hline p value & 0.001 & 0.424 & \\
\hline
\end{tabular}

In the pre-intervention, study group had a Mean Respiratory rate value of $17.40 \pm 2.13$, which has been decreased to $14.73 \pm 1.04$ in the post intervention, which was found to be highly significant $(\mathrm{P}=0.001)$. Similarly, the control group had a mean RR value of $17.39 \pm 2.03$ which has been decreased to $17.01 \pm 1.13$, the decrease was not statistically significant $(\mathrm{P}=0.424)$.

In the post intervention, study group had a mean RR (14.73 \pm 1.04$)$ and control group had a mean heart rate $(17.01 \pm 1.13)$ the change in the RR in the two groups differed. Whereas study group had greater decrease in SP compared to control group. Which was found to be highly significant $(\mathrm{P}=0.001)$.

\section{DISCUSSION}

After 3 months of study period, we observed a significant decrease in HR, SBP, DBP, MAP, PP, HR and RR only in OM Mantra Chanting along with Anulom Vilom Pranayama on Examination stress in medical and paramedical students (Study Group 1), on the other hand with no change in control group. However, trend towards insignificant decrease in HR, SBP, DBP, MAP, PP, HR and RR.

OM Mantra Chanting along with Anulom Vilom Pranayama involves manipulation of breath movement and the breath is a dynamic bridge between the body and mind. The psychosomatic effects of different pranayama are believed to derive from differences in duration of the phases of the breathing cycle, tidal volume and other factors including the use of mouth, nostrils, and constriction of the laryngeal muscles and position of the glottis [7]. Resting HR is determined mainly by parasympathetic tone and decrease in $\mathrm{HR}$ and $\mathrm{BP}$ indicates a decrease in sympathetic activity and / or increase in parasympathetic activity [8].

Our results demonstrate that there was a significant reduction in $\mathrm{RR}$ in Anulom Vilom pranayama group. On the contrary, there was no significant increase in RR in the control group. There was statistically insignificant, but definite trend towards decrease in HR, SBP and DBP in the pranayama group.
According to the traditional wisdom of yoga, pranayama is the key for bringing about psychosomatic integration and harmony. By voluntarily controlling breathing pattern, it is possible to influence ANS functions [9]. Our results are in agreement with that of Raghu Raj et al., in found practicing fast pranayama like Kapalabhati for 12 weeks lead to decrease in sympathetic activity [10]. Another study conducted by Kullok et al., in explained changes in autonomic activity by breathing exercises on the basis of known anatomical asymmetries in the respiratory, cardiovascular and nervous system and that the coupling mechanisms between each of these systems: lung heart, heart-brain and lungs-brain are also asymmetrical [11].

Similar results were observed in previous studies which found significant decrease in BP with the practice of Savitri Pranayama. Resting HR is mainly determined by parasympathetic nervous system (PNS) and DBP is a function of peripheral vascular resistance (PVR) which is mainly determined by sympathetic nervous system (SNS) [12]. MAP is determined by both SNS and PNS and refers to the mean pressure throughout the cardiac cycle. Decrease in HR, DBP, and MAP represents increase in parasympathetic and decrease in sympathetic activity in Anulom Vilom pranayama group [13].

Non-significant increase in PP (15.23\%) was observed in Anulom Vilom pranayama group and no change was observed in other groups. Rise in PP represents better tissue perfusion. RPP represent sympathetic activity and are indirect measures of $\mathrm{O} 2$ consumption of heart or work load on heart [14]. Rise in PP with decreased RPP indicates that the tissue perfusion is increased with decreased work load on heart in Anulom Vilom pranayama group. Therefore, our study demonstrates that decrease in sympathetic activity and increase in parasympathetic activity and thereby, improvement of autonomic tone towards parasympatho-dominance was seen in Anulom Vilom pranayama groups but statistically significant change in measured physiological parameters was seen in only Anulom Vilom pranayama group. 
Bittoo Kumar Surlya \& Manila Jain; Sch Int J Anat Physiol, Mar., 2021; 4(3): 38-43

During above tidal inspiration (as seen in Hering Breuer's reflex), stretch of lung tissue produces inhibitory signals by action of slowly adapting stretch receptors and stretch of connective tissue (fibroblasts) localized around the lungs generates hyperpolarization currents, which are propagated through neural and non-neural tissues and both of them cause synchronization of neural elements in heart, lungs, limbic system and cortex. Inhibitory current synchronizes rhythmic cellular activity between cardiopulmonary center and central nervous system and also regulates excitability of nervous tissues indicative of state of relaxation. Hyperpolarization of tissues manifests itself in parasympathetic like change. Synchronization within the hypothalamus and the brain stem is mainly responsible for the parasympathetic response. Modulation of the nervous system and decreased metabolic activity is indicative of the parasympathetic state [15].

A long-term improvement in autonomic balance as well as in respiratory, cardiovascular and brain function can be achieved if mechanical forces are applied to the body with the aim of reducing existing imbalances of mechanical force vectors. This technique implies continually controlling the body functions for precise timings like in pranayamic breathing techniques [16].

Explanation of finding more effect with Anulom Vilom pranayamic breathing can be due to the reason that slow breathing has been found to increase baroreflex sensitivity, reduce sympathetic activity and chemo reflex activation in healthy subjects as well as hypertensives. [91] Furthermore, strongest cardioventilatory coupling is seen when there is decreased breathing frequency like slow pranayamic breathing [17]. Increase in parasympathetic activity decreases resting HR and decrease in sympathetic tone in skeletal muscle blood vessels decreases PVR resulting in decrease in DBP, MAP, reduced work load on heart and improved tissue perfusion [18].

Yoga consists of different type of practices, most common of which is Anulom Vilom pranayama. Different pranayama produces different physiological effects. A study conducted by Joshi et al in which they found that yogic Asanas and pranayama reduce the resting respiratory rate and increase vital capacity, timed vital capacity, maximum voluntary ventilation, breath holding time and maximal inspiratory and expiratory pressures [19]. They concluded pranayama sessions in young male volunteers. The results of the study showed that there was a decrease in both expiratory and inspiratory muscle strength, alveolar hypoventilation due to depression of hypoxic and hypercapnoeic ventilatory drives and decrease in maximal breathing and diffusing capacity [20].
We propose that these changes may have occurred by pranayama practice due to improved autonomic tone towards parasympathodominance resulting in hypo metabolic state, relaxed state of mind and improved cardiac vagal tone. When the mind is relaxed and resting, parasympathetic activity increases and RR decreases. Increase in parasympathetic activity decreases resting HR and decrease in sympathetic tone in skeletal muscle, blood vessels, decreases peripheral vascular resistance and hence, decrease in DBP and improved tissue perfusion. Further our study substantiates the claim that Anulom Vilom pranayama practice is beneficial on cardio-respiratory function in healthy, volunteers.

\section{LIMITATION OF THE STUDY}

In the present study, it was not possible to attempt double blind conditions. Only single composite questionnaire was used to measure perceived stress. Future studies should include biochemical parameters such as oxidants and antioxidants along with other personality scales, which could be related to stress levels. Therefore, the results can be considered to be preliminary and be viewed with caution of potential rather bias. No significant clinical side-effects (confusion, cardiovascular accidents, dyspnea etc.) occurred with pranayama practice during the study period. In future, we are planning to extend this study further with more number of subjects and duration of yoga training on stress subjects as well as patients.

\section{CONCLUSION}

To summarize, our study demonstrates that pranayama practice is effective in reducing perceived stress but significant benefit on physiological parameters is seen in only study subjects practicing pranayama. Pulmonary function test parameters were recorded as before and after sessions. Our results showed significant increase in pulmonary function parameters after regular practice of pranav Anulom Vilom pranayama. The present study has shown that adding comprehensive yoga based breathing exercises (OM Mantra Chanting along with Anulom Vilom Pranayama) to the daily life to improve the lung function.

\section{REFERENCES}

1. Buchheit, M., Al Haddad, H., Laursen, P. B., \& Ahmaidi, S. (2009). Effect of body posture on postexercise parasympathetic reactivation in men. Experimental physiology, 94(7), 795-804.

2. Anad, B. K., China, G. S., \& Singh, B. (1961). Some aspects of electroencephalographic studies in yoga. Electroencephalography and Clinical Neurophysiology, 13, 452-456.

3. Jain, S. C., \& Talukdar, B. (1993). Evaluation of yoga therapy programme for patients of bronchial asthma. Singapore medical journal, 34, 306-306. 
Bittoo Kumar Surlya \& Manila Jain; Sch Int J Anat Physiol, Mar., 2021; 4(3): 38-43

4. Mason, R. A. (2001). Audiation, cochlear function, and the musical ear of Alfred Tomatis. Dissertation Abstracts International, 63:956.

5. Watkins, G. R. (1997). Music therapy: proposed physiological mechanisms and clinical implications. Clinical nurse specialist, 11(2), 4350 .

6. Hyde, I. H., \& Scalapino, W. (1918). The influence of music upon electrocardiograms and blood pressure. American Journal of PhysiologyLegacy Content, 46(1), 35-38.

7. Bernardi, L., Sleight, P., Bandinelli, G., Cencetti, S., Fattorini, L., Wdowczyc-Szulc, J., \& Lagi, A. (2001). Effect of rosary prayer and yoga mantras on autonomic cardiovascular rhythms: comparative study. Bmj, 323(7327), 1446-1449.

8. Knight, W. E., \& Rickard, N. S. (2001). Relaxing music prevents stress-induced increases in subjective anxiety, systolic blood pressure, and heart rate in healthy males and females. Journal of music therapy, 38(4), 254-272.

9. Burns, J., Labbé, E., Williams, K., \& McCall, J. (1999). Perceived and physiological indicators of relaxation: as different as Mozart and Alice in chains. Applied psychophysiology and biofeedback, 24(3), 197-202.

10. Chafin, S., Roy, M., Gerin, W., \& Christenfeld, N. (2004). Music can facilitate blood pressure recovery from stress. British journal of health psychology, 9(3), 393-403.

11. Möckel, M., Röcker, L., Störk, T., Vollert, J., Danne, O., Eichstädt, H., ... \& Hochrein, H. (1994). Immediate physiological responses of healthy volunteers to different types of music: cardiovascular, hormonal and mental changes. European journal of applied physiology and occupational physiology, 68(6), 451-459.

12. Buchheit, M., Al Haddad, H., Millet, G. P., Lepretre, P. M., Newton, M., \& Ahmaidi, S.
(2009). Cardiorespiratory and cardiac autonomic responses to 30-15 intermittent fitness test in team sport players. The Journal of Strength \& Conditioning Research, 23(1), 93-100.

13. Chacon-Mikahil, M. P. T., Forti, V. A. M., Catai, A. M., Szrajer, J. S., Golfetti, R., Martins, L. E. B., ... \& Maciel, B. C. (1998). Cardiorespiratory adaptations induced by aerobic training in middleaged men: the importance of a decrease in sympathetic stimulation for the contribution of dynamic exercise tachycardia. Brazilian Journal of Medical and Biological Research, 31(5), 705-712.

14. Clausen, J. P. (1977). Effect of physical training on cardiovascular adjustments to exercise in man. Physiological reviews, 57(4), 779-815.

15. Corby, J. C., Roth, W. T., Zarcone, V. P., \& Kopell, B. S. (1978). Psychophysiological correlates of the practice of Tantric Yoga meditation. Archives of General Psychiatry, 35(5), 571-577.

16. Craty, Mc, R., Atkinson, M., \& Tiller, W. A. (1993). Subtle Energies and Energy, Medicine Journal, 4(3):201-204.

17. Dash, M., \& Telles, S. (1999). Yoga training and motor speed based on a finger tapping task. Indian Journal of Physiology and Pharmacology, 43, 458-462.

18. Telles, S., \& Desiraju, T. (1991). Oxygen consumption during pranayamic type of very slow-rate breathing. The Indian journal of medical research, 94, 357-363.

19. Garg, M., Lata, H., Walia, L., \& Goyal, O. (2013). Effect of aerobic exercise on auditory and visual reaction times: a prospective study. Indian $J$ Physiol Pharmacol, 57(2), 138-145.

20. Brebner, J. T., \& Welford, A. T. (1980). Introduction: a historical background sketch. In Welford, A. T. (Ed.) Reaction Times. New York Academic Press. 1-23. 